\title{
THE ORDINANCE OF 1667: IDEOLOGY OF MODERN CODification as a Political ToOL OF LOUIS XIV*
}

\author{
ANNA KLIMASZEWSKA**
}

\section{INTRODUCTION}

In his The Sublime Object of Ideology Slavoj Žižek underscores that "Ideology is not a dreamlike illusion that we build to escape insupportable reality; in its basic dimension it is a fantasy-construction which serves as a support for out 'reality' itself. It is an 'illusion' which structures our effective, real social relations and thereby masks some insupportable, real, impossible kernel [...] The function of ideology is not to offer us a point of escape from our reality but to offer us the social reality itself as an escape from some traumatic, real kernel." In its political dimension, ideology soothes social antagonisms, "[as it] masks the reality [...], creating a fantasy-construction which allows the system to keep functioning". 2 According to Žižek, the ideological fantasy-construction fulfils the role of a "framework" which we place over the raw facts of reality in order to understand it. ${ }^{3}$ A special role in shaping these ideological frameworks is given to legal acts, which not only define accepted standards of behaviour, but also a certain vision of the world, of the political, social and economic system. The strongest expression of the created ideology is not only the final effect in the form of an enacted legal act, it is also (perhaps primarily so) the stage of preparatory works, at which the true intentions of the legislator are often manifested most evidently.

In this article, I discuss the process of development of certain ideological frameworks serving the purpose of "masking the reality", using the example of preparatory works leading up to the enactment of the 1667 Ordonnance sur la réformation de la justice civile, as well as the contents itself of this ordinance, enacted on the order of the French king Louis XIV, and commonly called the "Ordinance on civil procedure" (by its

\footnotetext{
DOI: $10.1515 /$ wrlae-2015-0028

* The present paper has been prepared within the framework of a project financed by the National Science Centre (Narodowe Centrum Nauki) on the basis of decision no. DEC2013/09/B/HS5/02617.

** Department of History of Law, Faculty of Law and Administration, University of Gdańsk.

${ }^{1}$ Slavoj Žižek, The Sublime Object of Ideology (Verso 2008) 16.

${ }^{2}$ Rafał Mańko, 'Koncepcja interpelacji ideologicznej a krytyczny dyskurs o prawie' [The Notion of Ideological Interpellation and Critical Discourse on Law] (2014) 1 Archiwum Filozofii Prawa i Filozofii Społecznej 43.

3 Žižek (n 1) 138; Mańko (n 2) 43.
} 
contemporaries as well as today- in textbooks, commentaries, jurisprudence, etc.). This is because a legal act, in theory passed with the purpose of regulating the civil procedure (and as such, permanently classified in the social reception), in principle consolidated the standards of judicial proceedings shaped over previous centuries. The basic innovative load that it carried was the change of entitlements and position within the system of judges, especially of those most highly placed (besides the king) within the hierarchy of the judicial system, that is of judges of the parliaments. Its promulgation marked an important step towards the building of an absolute monarchy in France.

The catchy propaganda phrases used by Louis XIV and the people employed by him for the task basically oscillated between steps taken up in social interest, for the good of the subjects (elimination of the abuses of the justice system, abolishment of arbitrary decisions made by judges and reduction of the costs of proceedings), as well as around the lofty work of codification of the law, which is marked with an atmosphere of taking the law a notch higher, of modernization and modernity. This is because codification, even when employed in order to solidify the ruler's authority, is inherently linked with the paradigm of progress, positively viewed by the society regardless of the legislator's original intentions.

This article comprises three major parts: first I explain the significance of the 1667 Ordinance, I then move onto the political circumstances in which it was enacted, before finally considering the steps taken in the battle for power of Louis XIV and his acolytes, in the course of which one of the tools was the legislative works on civil procedure.

\section{SIGNIFICANCE OF THE 1667 ORDINANCE}

In April of 1667, Louis XIV issued the Ordonnance sur la réformation de la justice civile, which regulated civil procedure. This was an unprecedented occurrence for many reasons. It was the first act in the series of so-called great ordinances, which constituted the first complex attempt at codification of French law, leading it onto a path of unification aimed at the level of national authority. Some of the Napoleonic codes went on to copy the contents of ordinances drafted under the reign of Louis XIV to various extents. ${ }^{4}$ The objective of this monarch, long before Bonaparte, was to "work

\footnotetext{
${ }^{4}$ The Commercial Code of 1807 was largely based on the Ordinance on commerce of 1673 and on the Ordinance on the marine of 1681. See Anna Klimaszewska, Code de commercefrancuski Kodeks handlowy z $1807 \mathrm{r}$. [Code de Commerce: The French Commercial Code of 1807] (Arche 2011). The majority of solutions from the ordinance of 1667 were duplicated in the Code of Civil Procedure of 1806, a fact openly admitted in the materials from preparatory works of the Napoleonic codification commission who worked on the project of the code. These materials have been repeatedly published, for instance in: Code de procédure civil, motifs et rapports, edition stereotype faite au moyen de matrices mobiles en cuivre, procédé d'Herhan (Garnery, Librairie Stéréotype Nicolle 1806). Even the materials from works on the reform of substantive civil law, conducted at the consent of Louis XIV, were later used to a large extent in drafting of the Code civil. According to J.P. Royer, the principle of copying regulations from the ordinances of Louis XIV by Napoleonic codification commissions also applied to penal procedure; Jean-Pierre Royer, Histoire de la justice en France (PUF 2001) 38.
} 
on the system of justice in his kingdom" (de travailler à la justice de son royame) and to develop a "great collection of French laws" (grand corps de droit français).

The longevity of the Ordinance on civil procedure was also remarkable. From a formal perspective, it remained in force until 1806, when the Code de procedure civile was enacted, however this code largely repeated the norms contained in the ordinance. Therefore, it would be difficult to speak of a new code; de facto it was rather an amendment of the ordinance of Louis XIV. As a result, it constituted an absolutely ground-breaking act in terms of the regulation of the law of civil procedure, laying the foundations for the French model in this legal field.

The preamble to the Ordinance emphasized the significance that the ruler attached to the principles of the work of the justice system, denominating this sector of the state authority as "the most solid foundation ensuring the continuation of the State, peace of the families and happiness of the nation." "However, it was simultaneously admitted that in this regard the state was not functioning properly. The very same preamble condemned the arbitrariness of courts, the excessive procedures and costs of proceedings, due to which the judiciary was ineffective in satisfying the needs of the subjects. ${ }^{6}$ The ordinance was viewed as the necessary remedy to this situation, especially since it was to have the semblance of the effect of a consensus reached by the ruler and the jurists, who to some extent represented the society. However, the propagandist and catchy phrases of the preamble, focusing on the social interest did not mean that the political interests of the monarch, who aimed to strengthen the state and his own absolute power, did not underlie the codification of the civil procedure. Both these objectives did not have to be mutually exclusive, after all. An ordinance on civil procedure could very well both further the interests of the state and constitute an important modernising tool. The codification may certainly be perceived in the categories of progress, a phenomenon that fostered the interests of the general society.

\section{Political Background}

The principles drafted by legists ${ }^{7}$ as early as the 13 th century clearly underscored the sovereign and absolute nature of the king's power ("the king is emperor in his realm"), also in the domain of justice ("the king is the fountain of all justice"). As a result of the expansion of royal judiciary, a

\footnotetext{
${ }^{5}$ Preamble to the ordinance, version used here: Ordonnance de Louis XIV. Roy de France et de Navarre. Donnée à Saint Germain en Laye au mois d'Avril 1667 (Associez choisis par ordre de Sa Majesté pour l'impression de ses nouvelles ordonnances 1667) 1.

${ }^{6}$ ibid 2.

${ }^{7}$ Legists - scholars of the Roman law, as opposed to specialists in canon law (canonists or decretalists); in France the legists were king's counsellors (usually officials originating from the small gentry or from the bourgeoisie), who strove to extend the king's power and who justified the need for a strong royal authority based on Roman law texts. They aided in the consolidation of the principles of succession to the throne, of the integrity of the king's domain and of those defining the king's general position within the monarchy. They are referred to as "the first creators of absolutism in France".
} 
separate judicial body emerged in the 13th century from the Royal Council, called the Parliament (Parlement) from the 14th century onwards. ${ }^{8}$ It had become impossible for the Council and the king to resolve the growing influx of cases. At the same time, it was inadvisable to bestow these competences onto unprofessional vassals. As a result, a group of legists was formed. They were educated jurists with a permanent delegation to adjudicate in the name of the king and in his absence. Since the early 14th century, Parliament functioned regularly as the supreme royal court with its permanent seat in the Cité, with professional judges (irremovable as of the 15th century). With the Parliament of Paris increasingly overburdened, kings begun to create new parliaments in individual provinces. ${ }^{9}$ Formally, the position of all parliaments as supreme courts was equal. In practice, the one in Paris, with jurisdiction over more than half of the kingdom, played a central role. ${ }^{10}$

Besides judicial competences, parliaments eventually acquired very serious legislative powers, connected to the procedure of registration of legal acts issued by the king. Following this registration, each of these acts was then published and it came into effect within the jurisdictions of separate tribunals. In principle, this took place through the reading of an act aloud in open sessions, followed by its copying into the register and sending a printed version to subordinate courts. However, as time passed, parliaments began to desire a more significant role, claiming that the process of registration far exceeded the simple procedural steps, as it consisted in legalizing each separate legal act by its acceptance and publication.

In order to justify the claims of parliaments, an entire ideological foundation was required. ${ }^{11}$ The 16th-century school of constitutionalists played a key role in this respect. For the larger part, they shared the views of the theorists on absolutism. They accepted, for example, the absolute power of the king, who wielded it in accordance with God-given and natural law. Unlike the absolutists, however, the constitutionalists raised the argument that the king's power was additionally limited by French law and customs. In their opinion, the essential nature of this power was not breached by this limitation,

\footnotetext{
${ }^{8}$ The subject of the genesis, structure, composition and competences of the Parliament of Paris has been the focus of numerous publications, e.g. Ernest Désiré Glasson, Le Parlement de Paris. Son rôle politique depuis le règne de Charles VII jusqu'à la Révolution, vol 1-2 (Librairie Hachette 1901); Philippe Payen, Les arrêts de règlement du Parlement de Paris au XVIII siécle. Dimension et doctrine. Les grandes thèses du droit français (PUF 1997); JeanBaptiste Dubédat, Histoire du Parlement de Toulouse, vol 1-2 (A Rousseau 1885); Gustave Saulnier de la Pinelais, Le gens du roi au Parlement de Bretagne 1553-1790 (J Plihon et L Hommay, A Picard 1902); also in English: John Hurt, Louis XIV and the parlements (Manchester University Press 2002); Joseph Hugh Shennan, The Parlement of Paris (Cornell University Press 1968); Bailey Stone, The Parlement of Paris, 1774-1789 (University of North Carolina Press 1981).

${ }^{9}$ Among others: in Toulouse (1443) for Languedoc and neighbouring territories; in Grenoble (1453) for Dauphiny; in Bordeaux (1462) for Guyenne and Western Gascony; in Dijon (1476) for Burgundy; in Rouen (1499) for Normandy; in Aix (1501) for Provence; in Rennes (1554) for Britanny; in Pau (1620) for Béarn and Navarre and in Metz (1633) for the dioceses of Metz, Toul and Verdun.

${ }^{10}$ It was also composed of a higher number of judges - over two hundred, while the provincial parliaments usually had between fifty and one hundred.

${ }^{11}$ Cf Étienne Pasquier, Les recherches de la France (Laurens Sonnius 1621); Bernard de la Roche-Flavin, Treize livres des Parlements de France (M Berjon 1621); Claude de Seyssel, La grand' monarchie de France (E Groulleau 1558); William Farr Church, Constitutional Thought in the Sixteenth-Century France (Harvard University Press 1941).
} 
as it was accepted voluntarily. Therefore, they perceived the king's power to be both absolute and limited. According to their outlook, the king's power could only be executed following its verification (vérification) by the parliaments. This process, they claimed, required the detailed examination of legal acts, aimed to detect possible contradictions in abstracto with the broadly understood notions of reason and justice, in concreto with the king's ordinances and jurisprudence of precedential nature. ${ }^{12}$

Such a far-reaching interpretation of the role of parliaments could not be meet with the approval of an absolute ruler. He had no resort but to accept it, however, as the stance of the parliaments, in clear opposition to the monarch, gained widespread acclaim in society. Especially since the EstatesGeneral were not summoned, the parliaments assumed the role of guards of fundamental rights. Following the death of Louis XIII, the scales seemed to definitely tip in favour of the parliaments and other central bodies of authority. They attempted to use the tumultuous political situation which ensued in connection with the minority of the new ruler, Louis XIV. They began to act much more forcefully than before. In 1648 Chief Minister of France, Cardinal Mazarin, who co-ruled the country in the period of minority of Louis XIV, struggled against the Great Council (Grand Conseil). The Chamber of Accounts (Chambres de comptes), the Board of Excise (Cour des aides) and the Parliament of Paris demonstrated their solidarity by establishing an assembly of the delegates of sovereign courts of Paris (l'assemblée de la chambre Saint Louis), on the basis of Arrêt d'Union passed in May of the same year ${ }^{13}$. Of course, such a wilful act of defiance went against the already solidified absolutist systemic principles, and it was designed to permanently tip the balance of power in favour of the parliaments: the king was to maintain the authority to propose, and the sovereign courts - to decide. The monarch's

\footnotetext{
12 This examination took place at plenary sessions of the combined chambers, at which a given act was read aloud in its entirety, analyzed and scrutinized through discussion. Subsequently, the members of the chambers would express their approval or lack thereof in a free vote (liberté de suffrages). Additionally, according to the constitutionalists, if a new law did not stand the procedure of verification, the parliament was entitled to strike the articles it did not accept. Parliaments could also, in their opinion, modify the law by adding articles drafted on the spot in order to solve any disputed issues. Both these procedures were referred to as modification. Moreover, the constitutionalists deemed it natural that parliaments that modified laws should not bother the king with information about it. Another manoeuvre employed by the parliaments in order to obstruct regulations they did not approve of was to drag out the procedure of registration for as long as possible. If this was not detected for long enough, the new regulations would often fall into oblivion. Additionally, a serious delay could also influence the king's willingness to accept certain modifications in return for effective registration. The right of remonstrance (droit de remontrances) was another measure of blocking new legal acts. It consisted in lodging oral or written objection to the registration of a given act. Simply passing this idea through voting would freeze the registration process, while the subsequent steps, that is drafting, verification, accepting and sending the remonstrance to the king were usually a very lengthy process. The king could order the registration of a law by way of a special writ (lettre de jussion). The parliaments, however, usually tried to wrestle the king by sending more remonstrances, which could only be overridden with the king's personal appearance at the parliament's "bed of justice" (lit de justice). Therefore, the parliaments were able to recourse to a sort of suspending veto.

13 Sovereign courts were understood to be all those tribunals which delivered sovereign rulings in the last instance, in cases entrusted to them by the king. Their judgments could be repealed only by the king or his Council. Sovereign courts included the Great Council, the Chamber of Accounts, the Excise Board, the Cour de Monnaies and the parliaments.
} 
situation was not improved by the views disseminated without any obstacles by Omer Talon, avocat général of the Parliament of Paris ${ }^{14}$, who claimed that sovereign courts should, pursuant to the constitution of the kingdom, contribute to limiting royal power, as designated for the exercise of the "second power" (puissance seconde), which they did through refusal to register and through exercising their right of remonstrance ${ }^{15}$.

\section{REACTION OF LOUIS XIV}

Following the death of Cardinal Mazarin in 1661, Louis XIV proclaimed his personal rule. Over the subsequent months, the ruler took a series of steps to strengthen his position by reclaiming the lost instruments of governance (instruments de gouvernement). Among the tasks that he had set for himself, reforming the judicial system was of pivotal importance. ${ }^{16}$ "Excessive elevation of the parliaments was dangerous for the entire kingdom in the period of my childhood. They must be humiliated, not only in the context of the harm they have already done, but particularly in the context of harm they may still cause in the future." 17

The first king's move was to dismiss and exile some of the "haughtiest" (plus hardi) and most defiant judges of the Excise Board (Cour des aides). ${ }^{18}$ The fundamental idea behind this move was to set a harsh example for the entire system of justice, with particular emphasis on the parliaments. ${ }^{19}$

In September 1663 Jean-Baptiste Colbert, finance controller general closely connected to the king, went even further, by issuing Instruction pour les maîtres des requêtes, commissaires départis dans les provinces ${ }^{20}{ }^{2}$ which included guidelines for the intendants, commissaires and maitres des requêtes regarding the statistical data they were to collect. Besides gathering maps and general information on individual regions, their task was to secure documentation and draft reports on ecclesiastical, military and financial matters, as well as on issues related to the functioning of the judicial authorities, with particular stress on instances of corruption and abuses of power by the judiciary, as well as the jurisprudence approach adopted by judges and possible complaints in connection with these. This document was a harbinger of change, foretelling the move away from the "judicial monarchy" and toward the "administrative monarchy". It indicated that the

\footnotetext{
${ }^{14}$ Avocats généraux, (usually two of them per each tribunal), similarly to procureur général, were considered the so-called "king's men" (gens $d u$ roi), appointed by him personally. They usually functioned collectively as the public prosecution, responsible for enforcement of king's law and for his interests. Unofficially, they were headed by procureur général, who drafted the written documentation, while avocat général spoke before the tribunal.

${ }^{15}$ Dominique Bernard Rives (ed) Euvres d'Omer et de Denis Talon, avocats-généraux au Parlement de Paris, publiées sur les manuscrits autographes, vol 1 (A Égron 1821) 217.

${ }^{16}$ Charles Louis Dreyss, Mémoires de Louis XIV pour l'instruction du Dauphin, vol 2 (Didier 1860) 384 .

${ }^{17}$ Louis XIV, 'Mémoires pour l'instruction du Dauphin (Mémoires pour l'année 1661)' in Pierre Goubert, Mémoires pour l'instruction du Dauphin (Imprimerie nationale 1992) 66.

18 ibid 400 .

19 ibid.

${ }^{20}$ Pierre Clément, Lettres, instructions et mémoires de Colbert, vol 4 (Imprimerie impériale 1867) 27-43.
} 
centre of gravity in the field of power was about to shift from judges ${ }^{21}$ to intendants (commissaires) who were fully dependent on the king.

Colbert had high expectations for the intendants and for their influence on the local judiciary. He also hoped that the Instruction would standardize, unify and order the views and practical methods of action. Colbert wished to fit the general course of action into this one text. Intendants, as civil servants who enjoyed a broad scope of competences, were to represent an extension of the sovereign's will ${ }^{22}$. They were his agents in contact with the common people; their role was to find out about the needs and capabilities of the local communities and to evaluate the atmosphere within them. Moreover, as part of the division of retained justice ${ }^{23}$ (justice retenue), an intendant, based on the right of evocation, could preside over chosen cases at his discretion. At the same time, his competences overlapped ${ }^{24}$ with the competences of the first presidents of local parliaments, which often turned into embers of conflict. This was clearly visible both in the old, previously integrated provinces, and in the territories newly conquered by Paris. Especially in the latter, in places such as Alsace, Roussillon, Artois and Franche-Comté, the reform of state structures was facing numerous challenges, particularly in what concerned the system of justice. A serious crisis broke out, among others, in 1628 in Bordeaux, where the members of parliament opposed the claims of intendant Servien to judiciary functions and refused to register his lettres de commission. $^{25}$

By nominating Colbert a royal minister, the king also secured his institutional influence on the parliaments. His original intention was to reduce their role in French public life. In particular, he aimed to create a situation wherein the role of parliaments regarding the registration of legal acts would be purely passive, coming down to their automatic acceptance and entering in the registers, without any freedom to modify their contents or to delay these actions. Colbert's plan was also to exert a moderate, long-term pressure, in order to influence the parliaments gradually yet consistently.

\footnotetext{
${ }^{21}$ All of the judiciary (with the exception of patrimonial, church and municipal courts) was king's; the king was the supreme judge and on this account, he had the right to judge personally. The existing courts exercised their power only in his name and only on the basis of a royal delegation. The king, however, reserved the right to suspend such delegation and to adjudicate in cases chosen by him. As a result, there was a distinction between delegated justice (justice déléguée), exercised by royal courts (prevotal, bailliage, presidial and the parliaments) and retained justice (justice retenue), reserved for the king personally or for the King's Council. The King could also freely decide on the competence of a court for chosen cases. Through the appointment of commissary court, he could indicate special judges to examine a given case.

${ }^{22}$ Intendants were nominated by the king in the Council; they were not subject to any local control and fell directly under the King's Council. Their decisions could be appealed against only to the Council.

${ }^{23}$ Compare with information above.

${ }^{24}$ Intendants were to monitor the activities of courts outside of parliaments, which often resulted in conflicts. They also exercised the right of evocation, consisting in the withdrawal of any case, regardless of the advancement of proceedings, and remanding it to another court "for the good of the justice system". Intendants were also allowed to adjudicate, with the assistance of royal magistrates.

${ }^{25}$ Charles Bon François Boscherondês Portes, Histoire du Parlement de Bordeaux, vol 1 (Charles Lefebvre 1877) $446 \mathrm{ff}$.
} 
The turning point in this regard was the issuance of the ordinance on civil procedure, under the telling title of Ordonnance sur la réformation de la justice civile. Even the organization of the legislative work was planned so as to strengthen the position of Louis XIV in the field of power at the expense of the parliaments. The project was elaborated by a committee of counsellors of state, with the participation of outstanding and renowned lawyers, such as Barthélemi Auzanet. The fundamental ideological core of the project had been highlighted numerous times before, starting with the speech delivered by the king himself during a session in Louvre on 25 September 1665:

"For a long time now [...] it has been my desire to meet in this circle in order to bring justice to my kingdom. I know that my country needs it desperately for reason of chaos caused by the war and the years of my minority. I have long searched for the resources to remedy this chaos. This has never seemed an impossible feat to me, although I do appreciate the numerous challenges, which oblige me even more to engage in solving this matter. A ruler of ambition must put all his efforts into difficult affairs. I expect assistance and cooperation from you, for this task to be successful as I expect it to be, especially since I have decided to handle it with zeal and since the Council assembled today is not to stay for a year or a few years. I hope to use its services and to summon it to me until the end of my life." 26

As a consequence, the Council of Justice (Conseil de justice) was made permanent by Louis XIV. Colbert's uncle and member of the State Council, Henri Pussort, ${ }^{27}$ presided over its sessions. The fate of the ordinance on civil procedure, and especially of its provisions contained in title I, which were of key importance for the king's permanent advantage over the parliaments, hinged in particular on the ruler's ability to neutralize the opposition on the side of the Parliament of Paris. Initially, Louis XIV attempted to win the favour of the members of this court, and in particular of its first president. As previous practice had shown, the presidents usually had a strong influence over the remaining judges, although in reality their clout depended on the individual predispositions and skills. It was a commissary post, due to which the Parliament's president was perceived as a representative of the king, and accountable to him only. On the other hand, however, the Parliament's president needed the support of other judges, for which reason he could not manifest his dependency on the king too ostentatiously while working for the good of his office, by definition marked to a certain extent by the independence of the king's power.

The first president of the Parliament of Paris, Guillaume de Lamoignon, appointed in 1658, subjected himself to the king formally, declaring his full devotion and loyalty. His actions, however, were marked by a high degree of independence. He refused bribes, ${ }^{28}$ fiercely defended the parliament's prerogatives and the judges' freedom of adjudication; he also

\footnotetext{
${ }^{26}$ Francis Monnier, Guillaume de Lamoignon et Colbert. Essai sur la législation française au XVII siècle (Didier 1862) 46-47.

${ }^{27}$ Colbert himself, even if he attended some sessions, categorically refused to preside over them; ibid 70-71.

${ }^{28}$ Vie de M. Premier Président de Lamoignon, écrit d'après le mémoires du temps et les papiers de la famille (Nyon 1781) xxxiv-xxxv.
} 
criticized the king's grandiose military ambitions that put a devastating financial burden on the state. ${ }^{29}$

It was therefore no wonder that Louis XIV, fearing attacks not only from the first president, but also from the other judges, came to the conclusion that their active participation in works on the ordinance on civil procedure was inadvisable. They were initially kept a secret, but finally they came to Lamoignon's attention. Nevertheless, all of his attempts to actively join the drafting of the ordinance were met with the king's unfaltering resistance. ${ }^{30}$

But the participation of judges, even if only symbolic, was necessary to present the ordinance to society as an effect of consensus and broad consultations with various legal circles. Therefore, the text drafted by Pussort's commission was simply read out loud by the chancellor, article by article, to the delegates of the Parliament, in the presence of the members of the State Council, to enable the judges a limited opportunity to participate in introducing changes and in the process of unification while maintaining all the disciplinary rules of the session. ${ }^{31}$ The remarks made by judges were sometimes accepted ${ }^{32}$ in the scope directly regarding to the civil procedure, but any of their objections as to the provisions of political nature were always nipped in the bud with the same statement uttered by Pussort: "Such is the king's will.",33 Characteristically, discussion over Title I of the ordinance, which contained limitations of the parliaments' prerogatives, did not take place until the very last session. ${ }^{34}$

However, Title I of the ordinance had already been drafted by the Council of Justice in 1665. Four articles from this title were subjected to registration procedure. Of them, the most important was article IV, which regarded the registration duty. It enabled the king personally, but also through others acting as his proxies, to expedite the registration procedure. The socalled "bed of justice in the king's absence" (lit de justice roi non présent) was established. Thus, article IV allowed the king to introduce laws without any reservations or limitations foreseen by the practice of parliaments pertaining to the registration procedure, supported by the theoretical grounds provided by constitutionalists. In this way, Louis XIV forced through a reform that none of his predecessors managed to.

\footnotetext{
${ }^{29}$ Cf Discours de Guillaume de Lamoignon, the manuscripts at the National Library in Paris (Bibliothèque Nationale - BN), sign.: vol 1 - BN Fr 14051, vol 2 - BN Fr 14052.

${ }^{30}$ The king's answer was always the same: "Mr. Colbert currently employs Mr. Pussort for this job. See mister Colbert and follow his instructions" ibid.

${ }^{31}$ The king, as he confessed in his Mémoires, was keen to avoid any "annoying obstacles" (quelques chicane qui me fachât); Jean de Gain-Montagnac, Mémoires de Louis XIV, écrits par lui-même, composés pour le Grand Dauphin, son fils et adressés a ce prince, vol 2 (Garnery, Librairie Stéréotype Nicolle 1806) 6.

32 Although Lamoignon advocated that the principle of written form be observed, Pussort managed to render the proceedings more oral. For example, the presentation of disputed items in an articulated form (appointment) was reduced only to the most complex cases. Otherwise, evidence was presented during an oral hearing (Title XIV, art. 6).

${ }^{33}$ Monnier (n 26) 89.

${ }^{34}$ In the fifteenth and last session of 17 March 1667: Procès-verbal des conférences tenues par ordre du Roi pour l'examen des articles de l'Ordonnance civile du mois d'Avril 1667 et de l'Ordonnance criminelle du mois d'Avril 1670 (Associez choisis par ordre de Sa Majesté pour l'impression de ses nouvelles ordonnances 1757) $472 \mathrm{ff}$.
} 
One of the most strongly affirmed objectives of the legislative works was the replacement of old regulations with uniform norms regarding procedure, and thus the elimination of all provisions that stood in the way of generally shortening the length of civil proceedings. This was not about some fundamental restructuring of the heretofore functioning procedure, but rather about setting out its rules in an explicit and concrete manner. In this sense, the ordinance was the crown jewel in the evolution of the French model of civil procedure which had started some time before. Avoidance of abrupt changes in the ages-old matter, as well as the emphasis put on the pro-civic direction of the legislative works served, at the same time, as the ideological justification for actions which, incidentally, also limited the role of the parliaments in the whole process, thus debilitating their position.

The king's moves were in fact part of his consistent and long-term drive for power, played out under the ruse of a lofty reform of the justice system. In the 1667 ordinance, the term "sovereign courts" was replaced by "supreme courts". This was because, in an absolutist state, there was no space for the existence of any sovereign entities other than the monarch himself. Therefore, this small modification was in fact a momentous one in its ideological aspect. On a practical level, the provisions laying down disciplinary measures against judges who disregarded the norms set out in the royal legislation ${ }^{35}$ had a similar weight. This was clearly expressed in Article 6 of Title I: "Our will is for all of our ordinances, edicts, declarations and lettres patentes to be abided both in judgments and in other decisions, without any opposition; we do not wish for the courts or judges who represent us to feel exempt from them, nor to feel competent to modify their disposition, regardless of the case and matter, even under the pretence of rightfulness, public good or expedition of justice."

Nevertheless, the reform regarding the extraordinary appeal measures was much more important from the perspective of the judiciary. It abolished the tremendously strict proposition d'erreur, ${ }^{36}$ introducing instead the much more far-sighted cassation (cassation), a measure that made such a great carrer all over the world and became the hallmark of the French procedure. The very term "cassation" was not expressly employed until the decree of 1684, but its practical application was already suggested in Article 7 of Title I of the ordinance: "If, in the process of adjudication in a case pending before our parliaments or other courts, any doubts or difficulties that arise in connection with the execution of any of our ordinances, edicts, declarations, lettres patentes, we forbid their interpretation; in such cases it is our will for the [courts] to refer to us to be acquainted with our intention". The legal enquiries - designed as a tool for ongoing control of the judges' jurisprudential work - were lodged with the Council of Parties, which formed part of the King's Council. This institution bore fruit in the form of cassation as a competence to repeal (delete) final and binding judgements. Initially, this

\footnotetext{
${ }^{35}$ Earlier, the parliaments had at their disposal the right to apply disciplinary measures against their members.

${ }^{36}$ Claude Joseph de Ferrière, Dictionnaire de droit et de pratique, contenant l'explication des termes de droit, d'ordonnances, de coutumes et de pratique: avec les juridictions de France, vol 2 (J Dupleix 1779) 408. More Serge Dauchy, Les voies de recours extraordinaires : proposition d'erreur et requête civile (de l'ordonnance de Saint Louis jusqu'à l'ordonnance de 1667 (PUF 1989).
} 
was a method to withdraw a judgement delivered on the basis of a fact-related error, not a legal one, as the idea that supreme courts could apply the existing law incorrectly was inadmissible. ${ }^{37}$

Louis XIV concluded his game in the field of power by solving the problem of the parliaments dragging out the registration procedure, which he accomplished by way of articles 2 and 5 of Title I of the ordinance. From then on, the procedure had to be initiated immediately following the receipt of the legal act by courts, which were to "abandon all other matters". The right of remonstrance was limited to eight days for the Parliament of Paris and to six weeks for the others. Due to the "varied interpretations" of these regulations, a royal declaration was issued in 1673 (24 February), unequivocally upholding the abolishment of remonstrance prior to registration of legal acts. $^{38}$ Thus, the only effective way for the parliaments to obstruct the king's will was disarmed. Always the "master of pragmatism", ${ }^{39}$ Louis XIV did not in fact deprive them altogether of this right, for centuries deeply rooted in tradition; he rather shifted the center of gravity of how this right was exercised. Legal acts regarding the "proper movement" (propre mouvement) of the king had to be registered by obligation and without delay. Only later could the courts, if such need arose, draft a remonstrance. Although, according to Michel Antoine, the parliaments still maintained their security shield against the monarchy, and the introduced limitations failed to silence them altogether, ${ }^{40}$ it is clear that the right of remonstrance lost much of its force.

\section{CONCLUSIONS}

The enactment of the 1667 Ordinance marked a very significant reform of the law, which led France into a new era of codification in the domain of civil procedure. It was from that point on that France joined the avant-garde of states exemplary in terms of the direction of evolution of the law in the entire world. It was also a fundamental blow in the political battle between the king and the judicial authority, which should not be forgotten within the context of this legal act. The employment of clever social propaganda in this process constituted an element of a well-planned strategy which was to help curtail, without any social upheaval, the competences of parliaments, which were widely considered a bastion of opposition against the royal power; a strategy of which the 1667 Ordinance was one of the tools, as the reform of civil procedure set the official framework for actions taken

\footnotetext{
${ }^{37}$ See Marguerite Boutel-Sautel, 'La cassation sous l'Ancien Régime' in Le tribunal et la Cour de cassation (1790-1990) (Association des magistrats et anciens magistrats de la Cour de cassation 1990) 1-24; idem, Vivre au Royaume de France (PUF 2010) 453-476.

38 François-André Isambert, Decrusy, Alphonse Honoré Taillandier, Recueil général des anciennes lois françaises, depuis l'an 420, jusqu'à la Révolution de 1789, vol 19 (Librairie de Plon Frères 1829) 70-73.

${ }^{39}$ Royer (n 4) 34.

${ }^{40}$ Cf Michel Antoine, 'Les remontrances des Cours supérieures sous le règne de Louis XIV (1673-1715)’ (1993) 151 Bibliothèque de l’École des chartes 87-122.
} 
by Louis XIV, it enabled the proper "interpretation of the raw facts of reality". 41

Unable to explicitly declare his intention to deprive the parliaments of their competences, Louis XIV "claded" his objectives in the framework of progressive codification. Without excessively reforming the procedure itself, he revolutionized the position of judges within the legal system, as an addition to the great legislative work designed to protect citizens from the abuses of the judicial system.

\section{References}

Antoine M, 'Les remontrances des Cours supérieures sous le règne de Louis XIV (1673-1715)' (1993) 151 Bibliothèque de l'École des chartes.

Boscherondês Portes CBF, Histoire du Parlement de Bordeaux, vol 1 (Charles Lefebvre 1877).

Boutel-Sautel M, 'La cassation sous l'Ancien Régime' in Le tribunal et la Cour de cassation (1790-1990) (Association des magistrats et anciens magistrats de la Cour de cassation 1990).

_, Vivre au Royaume de France (PUF 2010).

Church W, Constitutional Thought in the Sixteenth-Century France (Harvard University Press 1941).

Clément $\mathrm{P}$, Lettres, instructions et mémoires de Colbert, vol 4 (Imprimerie impériale 1867).

Code de procédure civil, motifs et rapports, edition stereotype faite au moyen de matrices mobiles en cuivre, procédé d'Herhan (Garnery, Librairie Stéréotype Nicolle 1806).

Dauchy S, Les voies de recours extraordinaires : proposition d'erreur et requête civile (de l'ordonnance de Saint Louis jusqu'à l'ordonnance de 1667 (PUF 1989).

Dreyss C, Mémoires de Louis XIV pour l'instruction du Dauphin, vol 2 (Didier 1860).

Dubédat JB, Histoire du Parlement de Toulouse, vol 1-2 (A Rousseau 1885).

Ferrière CJ de, Dictionnaire de droit et de pratique, contenant l'explication des termes de droit, d'ordonnances, de coutumes et de pratique: avec les juridictions de France, vol 2 (J Dupleix 1779).

Gain-Montagnac J de, Mémoires de Louis XIV, écrits par lui-même, composés pour le Grand Dauphin, son fils et adressés a ce prince, vol 2 (Garnery, Librairie Stéréotype Nicolle 1806).

Discours de Guillaume de Lamoignon, Bibliothèque Nationale de France, Département des Manuscrits, vol 1 - Fr 14051, vol 2 - Fr 14052.

Glasson E, Le Parlement de Paris. Son rôle politique depuis le règne de Charles VII jusqu'à la Révolution, vol 1-2 (Librairie Hachette 1901).

Goubert P, Mémoires pour l'instruction du Dauphin (Imprimerie nationale 1992).

Hurt JJ, Louis XIV and the parlements (Manchester University Press 2002)

${ }^{41}$ Žižek (n 1 ) 138; Mańko (n 2) 43. 
Isambert FA, Decrusy, Taillandier AH, Recueil général des anciennes lois françaises, depuis l'an 420, jusqu'à la Révolution de 1789, vol 19 (Librairie de Plon Frères 1829).

Klimaszewska A, Code de commerce - francuski Kodeks handlowy z $1807 \mathrm{r}$. [Code de Commerce: The French Commercial Code of 1807] (Arche 2011).

Mańko R, 'Koncepcja interpelacji ideologicznej a krytyczny dyskurs o prawie' [The Notion of Ideological Interpellation and Critical Discourse on Law] (2014) 1 Archiwum Filozofii Prawa i Filozofii Społecznej.

Monnier F, Guillaume de Lamoignon et Colbert. Essai sur la législation française au XVII siècle (Didier 1862).

Ordonnance de Louis XIV. Roy de France et de Navarre. Donnée à Saint Germain en Laye au mois d'Avril 1667 (Associez choisis par ordre de Sa Majesté pour l'impression de ses nouvelles ordonnances 1667).

Pasquier É, Les recherches de la France (Laurens Sonnius 1621).

Payen $\mathrm{P}$, Les arrêts de règlement du Parlement de Paris au XVIII siécle. Dimension et doctrine. Les grandes thèses du droit français (PUF 1997).

Procès-verbal des conférences tenues par ordre du Roi pour l'examen des articles de l'Ordonnance civile du mois d'Avril 1667 et de l'Ordonnance criminelle du mois d'Avril 1670 (Associez choisis par ordre de Sa Majesté pour l'impression de ses nouvelles ordonnances 1757).

Rives DB (ed), Euvres d'Omer et de Denis Talon, avocats-généraux au Parlement de Paris, publiées sur les manuscrits autographes, vol 1 (A Égron, 1821).

Roche-Flavin B de la, Treize livres des Parlements de France (M Berjon 1621).

Royer JP, Histoire de la justice en France (PUF 2001).

Saulnier de la Pinelais G, Le gens du roi au Parlement de Bretagne 15531790 (J Plihon et L Hommay, A Picard 1902).

Seyssel C de, La grand' monarchie de France (E Groulleau 1558).

Shennan JH, The Parlement of Paris (Cornell University Press 1968).

Stone B, The Parlement of Paris, 1774-1789 (University of North Carolina Press 1981).

Vie de M. Premier Président de Lamoignon, écrit d'après le mémoires du temps et les papiers de la famille (Nyon 1781).

Žižek S, The Sublime Object of Ideology (Verso 2008). 